\title{
O Luto do Jovem Adulto Decorrente da Morte dos Pais pelo Câncer
}

\author{
Ana Laura Araujo Busa ${ }^{1}$ \\ ${ }^{1}$ Centro Universitário Barão de Mauá, SP, Brasil. \\ Gabriela Braga da Silva ${ }^{1}$ \\ ${ }^{1}$ Centro Universitário Barão de Mauá, SP, Brasil. \\ Fernanda Pessolo Rocha \\ ${ }^{1}$ Centro Universitário Barão de Mauá, SP, Brasil.
}

Resumo: O presente estudo buscou compreender como os jovens-adultos lidaram com a terminalidade de um de seus pais pelo câncer, investigando os aspectos emocionais, tais como: tristeza, medo, insegurança, raiva e alívio; e também como o jovem vê e entende a vida durante esse processo. Para a coleta de dados, foram selecionados 4 jovens adultos de ambos os sexos, com idades entre 25 a 35 anos, que passaram pelo período máximo de 2 anos de luto. Os participantes responderam a uma entrevista individual e semiestruturada, a qual investigou os aspectos emocionais do luto, em seguida, foram analisadas com base nos pressupostos teóricos de Bardin (2010) e foram identificadas categorias temáticas. As subcategorias foram nomeadas e analisadas posteriormente; elas revelaram que a morte dos pais é uma situação dolorosa que desperta uma diversidade de sentimentos, como tristeza, medo, ansiedade e, algumas vezes, 0 alívio. O estudo revela a importância de uma rede de apoio psicossocial para essa população a fim de ajudá-la na elaboração do luto e minimizar seu sofrimento. Espera-se que, através dos dados coletados, possa emergir novas formas de ajuda psicológica para o melhor auxílio do enfrentamento do luto para essa faixa etária.

Palavras-chave: Jovem-Adulto, Luto, Câncer.

\section{Young Adult Mourning Due to Cancer's Death of Parents}

\begin{abstract}
This article aimed to comprehend the ways young-adults deal with the death of one their parents because of cancer, focusing on emotional aspects such as sadness, fear. insecurity, rage and relief. It also examined how these young-adults see and understand life during this process. For data collection, four young- adults, aged between 25 and 35 from both genders, were chosen. They all had gone through a period of mourning for no longer than two years. The participants responded to an individual- semi structured interview which investigated the emotional aspects of grief. The data, which were collected from the interviews, were analyzed qualitatively based on the theoretical assumptions of Bardin (2010) and thematic categories were identified. Subcategories were named and analyzed later on and they revealed that the death of a parent is a painful situation which awakens a variety of feelings, such as sadness, fear, insecurity and sometimes relief. This study shows the importance of a psychosocial network for this population in order to help them elaborate their mourning and minimize their suffering.
\end{abstract}

Keywords: Young Adult, Mourning, Cancer. 


\title{
El Luto del Joven Adulto Resultante de la Muerte de los Padres por el Cáncer
}

\begin{abstract}
Resumen: El presente estudio buscó comprender cómo los jóvenes adultos lidiaron la muerte de uno de sus padres por el cáncer, investigando los aspectos emocionales, tales como: tristeza, miedo, inseguridad, rabia y alivio; y también como el joven ve y entiende la vida durante ese proceso. Para la recolección de datos, fueron seleccionados 4 jóvenes adultos de ambos sexos, con edades entre 25 a 35 años, que pasaron por el período máximo de 2 años de luto. Los participantes respondieron a una entrevista individual y semiestructurada, la cual investigó los aspectos emocionales del luto, a continuación, se analizaron con base en los presupuestos teóricos de Bardin (2010) y se identificaron categorías temáticas. Las subcategorías fueron nombradas y analizadas después; éstas revelaron que la muerte de los padres es una situación dolorosa que despierta una diversidad de sentimientos, como tristeza, miedo, ansiedad y, algunas veces, el alivio. El estudio revela la importancia de una red de apoyo psicosocial para esa población a fin de ayudarla en la elaboración del luto y minimizar su sufrimiento. Se espera que, a través de los datos recolectados, puedan emerger nuevas formas de ayuda psicológica para el mejor auxilio del enfrentamiento del luto par este grupo de edad.
\end{abstract}

Palabras clave: Joven-adulto, Luto, Cáncer.

\section{Apresentação}

O luto é uma das dores mais difíceis de vivenciar, pois contém perdas reais e simbólicas. No processo de luto, a pessoa passa, com o decorrer do tempo, a retirar toda a energia libidinal que era depositada no falecido, para então poder superar essa dor (Freud, 2010).

Dessa forma, o enlutado precisa percorrer algumas fases comuns desse processo para consumação de seu luto, vivenciando sentimentos como raiva, desespero e tristeza; bem como sentimentos que o façam ter vontade de voltar a viver (Bowlby, 2004).

Pessoas acometidas pelo câncer em situações terminais necessitam possuir alguma explicação para seu infortúnio, por isso que reflexões sobre sua finitude se fazem presentes; e a família contém um papel muito importante, para auxiliar nesse processo de elaboração (Valle, 1997).

Assim, tendo em vista que a morte de um dos pais desperta uma diversidade de sentimentos, como raiva, medo e tristeza, as considerações a seguir terão como objetivo facilitar a compreensão da elaboração do luto e verificar as intervenções possíveis de serem realizadas pela equipe de saúde.

\section{Aspectos psicológicos da morte}

A morte faz parte do desenvolvimento humano e cada cultura reage a ela de forma diferente. Como produto da transformação da sociedade, sua percepção vem sofrendo alterações ao longo da história, passando de uma experiência tranquila, como ocorria na Idade Média, para algo causador de angústia, dor e aflição (Ariés, 2014).

No início da Idade Média, a morte envolvendo parentes, amigos e vizinhos era encarada com familiaridade. O moribundo ao sentir que poderia morrer recolhia-se ao seu quarto, pedia perdão por suas culpas, distribuía seus bens e esperava a morte chegar. A partir do século XVIII, a morte tomou outro rumo, passou a ser vista como uma transgressão que roubava o homem do seu cotidiano e da família e tornou-se um tabu, no qual todos buscavam afastar-se (Ariès, 2014).

$\mathrm{Na}$ sociedade atual, a presença dos familiares junto ao paciente terminal deu lugar ao ambiente frio e isolado do hospital, os rituais de morte foram substituídos pelas organizações funerárias, onde o ambiente é neutro e higiênico; pelos cortejos fúnebres, rápidos e discretos; e pelo autocontrole do enlutado que não pode expressar verdadeiramente suas emoções, a fim de não perturbar outras pessoas com algo tão mórbido (Maranhão, 1992).

O processo de luto é caracterizado pela perda de um elo significativo entre uma pessoa e seu objeto. Nesse sentido, entende-se que é um fenômeno natural e constante durante o desenvolvimento humano. 
O luto normal é uma resposta saudável a uma situação estressante, que é a perda significativa de um ente querido, implicando na capacidade de expressar a dor (Parkes, 1998).

Na escala filogenética, o homem é o único animal que percebe sua situação mortal. A consciência da morte faz parte das conquistas constitutivas dos homens, já não é mais uma questão de instinto, e sim a aurora do pensamento humano, que se traduz por uma espécie de revolta (Morin, 1997).

O medo da morte pode conter o medo da solidão, da separação de quem se ama e da interrupção dos sonhos e planos. Há várias perdas ao longo da vida e a concepção de morte depende da crença de cada pessoa. Por tradição cultural, familiar ou investigação pessoal, cada um traz dentro de si "uma morte", ou seja, sua própria representação, atribuindo-se personificação, qualidades e formas (Kovács, 2010).

Para o homem contemporâneo, a morte representa um acontecimento pavoroso e medonho. Não tendem a encarar abertamente seu fim de vida na Terra; só eventualmente e com certo temor é que lançará um olhar sobre a possibilidade de sua própria morte. Uma dessas ocasiões é a consciência de que sua vida está ameaçada por uma doença (Moraes, 1994).

Com o avanço da tecnologia, a realidade da morte é negada, parecendo ser algo distante e fantasioso, como se não pudesse ocorrer na vida de cada um. Nessa situação, a externalização dos sentimentos pelo paciente e a compreensão dos afetos sentidos são fundamentais para a aceitação da morte, pois assim como o nascer, a morte faz parte do processo da vida humana (Kübler-Ross, 2008).

Segundo a autora em questão, a morte não deve ser temida, pois ela pode se transformar numa experiência enriquecedora, sendo que tudo depende da forma como o sujeito olha para as situações. Há muitas razões para se fugir de enfrentar a morte, uma das mais importantes é que morrer parece triste demais, é muito solitário, mecânico e desumano.

Há uma associação da angústia da morte à dor, crueldade, solidão e ao abandono. Não se trata apenas de um fato biológico, mas profundamente humano. A morte representa ausência, perda, desamparo, separação. É um território desconhecido, imprevisível, inexplorado, nunca antes vivido (Jaramillo, 2006).

\section{$O$ câncer e a morte}

Atualmente, o câncer carrega o estigma de doença fatal, por estar culturalmente ligado à ideia de morte. O medo da doença se faz muito presente após o diagnóstico, promovendo uma intensificação da dor que antes da descoberta não era tão frequente. $\mathrm{O}$ mesmo não ocorre com outras doenças que levam em consideração a possibilidade da morte, mas o câncer leva à fantasia de destruição (Carvalho, 2003).

Câncer é o nome dado há mais de 100 tipos de doenças que possuem em comum a sua proliferação celular, provindas de um crescimento desordenado, incontrolável e agressivo, podendo ser rápido (maligno) ou lento (benigno), invadindo órgãos e tecidos e se espalhando por várias regiões do corpo. A sua multiplicação determina os tumores ou neoplasias malignas (INCA, 2016).

As causas orgânicas que levam ao câncer podem ser externas ou internas, no entanto, há uma correlação entre ambas. As variáveis que influenciam o meio externo são: o ambiente, os costumes e hábitos que variam de acordo com cada cultura, sendo fator predominante em relação à causa da doença. Já os motivos internos, geralmente, são derivados de uma pré-determinação genética. O seu surgimento procede de uma alteração do DNA e de genes normais, que recebem instruções erradas para desenvolver suas atividades, o que na literatura costuma chamar de mutação genética (INCA, 2016).

Segundo Carvalho (2010) o câncer é considerado uma doença psicossomática, que se depara com alguns traumas específicos e condições psicológicas. O autor aponta a influência dos traços de personalidade, como, por exemplo, características passivas, são de pacientes considerados como menos adaptativos em relação ao mundo, e mais adaptativos na aceitação da doença, podendo os levar a ter pouca adesão ao tratamento e a viver menos. O mesmo não acontece com as pessoas que são consideradas como mal adaptativas em aceitar o fato de estar com câncer, fazendo com que elas possam viver mais e responder melhor ao tratamento.

Dessa forma, o autor assegura que os traços de personalidade apresentam grande relevância, pois dizem muito sobre como o paciente vai lidar com a doença e reflete também como o paciente lidava com sua vida, com seus problemas e situações estressoras (Carvalho, 2010). 
Teixeira (2006) enfatiza a influência do convívio da família no desenvolvimento do câncer, como mudanças fugazes de vínculo e os conflitos familiares. Além de salientar também algumas características de personalidade, tais como pouca agressividade e hipersensibilidade.

$\mathrm{O}$ autor citado acima, afirma que o paciente e seus familiares que se deparam com o câncer acabam tendo de administrar todo o processo relativo ao tratamento: cirurgias, dietas, terapêuticas medicamentosas, prognóstico, alterações psicológicas e mudança na rotina. Todas essas alterações na vida do paciente, bem como na relação familiar, se refletem em muitas confusões nos pensamentos e sentimentos.

O paciente acometido por doença grave necessita ter alguma razão que explique sua desventura, sendo importante a busca de uma elaboração que relaciona seu passado, seu presente e o seu futuro, proporcionando assim, sentido para o vazio que esses pacientes acabam vivendo (Valle, 1997).

Essas angústias também se refletem na família, a partir do momento que recebem a notícia do diagnóstico, que costuma causar impacto. A família pode elaborar uma perda antecipada na medida da evolução da doença, que muitas vezes pode originar padrões de conflitos disfuncionais na relação familiar, principalmente após o falecimento (Cunha, Freitas, \& Oliveira, 2011).

Desse modo, é feita uma reconstrução do que foi vivido e dessa nova realidade que se impõe tanto para o doente como para a família, conferindo assim ressignificações que, de certa forma, procede a um determinado domínio para vida (Valle, 1997).

Ao ocorrer a morte causada pelo câncer, tornam-se esperadas as angústias, confusão nos pensamentos e também sentimentos do novo que se apresentam para a pessoa. Junto com as angústias, aparece também uma determinada carência de palavras a ser posta e a necessidade em pensar sobre a morte, podendo emergir sentimentos de desamparo e solidão (Teixeira, 2006).

\section{0 processo de luto para o jovem adulto}

O período compreendido como "jovem adulto" é aquele que percorre dos 20 aos 40 anos. Essa etapa é descrita como o ápice do desenvolvimento físico e cognitivo. As expectativas prescritas para essa etapa giram em torno de definições profissionais, da conquista da autonomia e de relacionamentos mais está- veis no que tange à sexualidade e à constituição familiar (Olds, \& Papalia, 2013).

De acordo com Papalia e Olds (2013), os jovens adultos geralmente estão no auge de sua força, energia e resistência. A maioria dos sentidos estão mais apurados durante o início da idade adulta e as condições tendem a ser favoráveis. Segundo a Organização Mundial de Saúde, a saúde é um estado de total bem-estar físico, mental e social e não simplesmente a ausência de doença ou debilidade. Dessa forma, uma vida saudável não é apenas uma questão de sorte, ela geralmente reflete um estilo de vida e uma série de escolhas.

É nesse período, usualmente, que as pessoas formam relacionamentos baseados em amizade, amor e sexualidade que podem se estender pela maior parte de suas vidas adultas. A intimidade inclui a ideia de pertencer a alguém, formar relacionamentos fortes, estáveis e amorosos, é um poderoso motivador do comportamento humano, o qual afeta a mente e o corpo.

As exigências externas constituem um estado íntimo que fazem o indivíduo se sentir adulto. Muita energia é despendida na construção de todos esses pilares. O espaço da morte na consciência ainda pode estar muito distante; o impulso da adolescência tende a diminuir e, em geral, a pessoa se torna mais ponderada e calma.

Segundo Kovács (2010), não se busca a vida eterna, mas sim a juventude eterna, repleta de prazeres, força, beleza, e não a velhice eterna, com sua feiura, suas perdas e dores. Não se acredita na própria morte, o indivíduo age como se ela não existisse, faz planos, cria obras e filhos, imaginando que estes perpetuarão o ser.

Cada vez mais, devido a fatores como a violência em diferentes âmbitos e as doenças infectocontagiosas, os jovens têm se deparado com a morte. A perda ocasionada pela morte da pessoa próxima, na maioria das vezes, provoca uma desorientação profunda na vida do jovem adulto. Assim, dependendo do vínculo criado com o falecido e da própria personalidade, pode ocorrer choque e desespero, fazendo com que este se sinta perdido. Além disso, a perda de uma pessoa próxima pode gerar a consciência da própria mortalidade (Domingos, \& Maluf, 2003).

No período de pós-perda, são vivenciados processos de elaboração do luto, no qual ocorrem fenômenos de enfrentamento de perdas significativas e 
de elaboração da dor. O período de vivência do luto costuma ser caracterizado por diversas mudanças. Além de ter que lidar com a perda, a pessoa pode ter que passar por rupturas na sua condição e no papel exercido como, por exemplo, uma pessoa que passa de filho para a de órfão (Papalia, \& Olds, 2013).

Quando o jovem adulto se depara com a morte de um dos genitores, irá passar pelo processo de luto. O luto pode ser um conjunto de reações emocionais (tristeza, solidão, culpa, ansiedade), físicas (vazio no estômago, aperto no peito, boca seca, fraqueza muscular), cognitivas (confusão, preocupação, alucinações) e comportamentais (distúrbios de sono, chorar, guardar objetos pertencentes ao morto) que surgem como resposta à perda (Parkes, 1998).

Para Bowlby (2004), a tristeza é sinal de saúde frente à infelicidade; e a não vivência desta tem consequências variáveis, geralmente prejudiciais e de grande mudança na vida do sujeito. $\mathrm{O}$ autor caracteriza tal atitude como sendo "mal adaptativa" na grande maioria dos casos.

É importante que as vivências relativas à morte sejam elaboradas e que permitam ao sujeito processos de ressignificação da vida e, consequentemente, rearticulação de projetos. Para tanto, faz-se necessário questionar os ritmos impostos pelos modos de vida contemporâneos, nos quais a pressa de resultados eficientes, previsíveis e imediatos delimita expectativas e comportamentos.

O processo de luto, destaca Kovács (2010), evoca sentimentos fortes e ambivalentes, sendo necessário tempo e espaço para a sua elaboração. A ocorrência da perda de uma pessoa significativa potencializa a desorganização, as ações do cotidiano ficam tingidas por essa situação.

As perdas fazem parte da vida: quando morre a mãe, morre também parte da nossa infância e adolescência; quando morre um filho, morre em nós o futuro previsto junto àquele ente querido, o sonho de vê-lo um profissional, pai de nossos netos, a pessoa que nos acompanharia até o fim de nossa vida (Zimerman, 2010).

Diante do exposto, considera-se importante refletir sobre a experiência do jovem adulto que vivencia o processo de luto, uma vez que nesses momentos, podem ficar desorientados, envolvidos por sentimentos de angústia e dor. A ausência do familiar poderá levar à solidão, e todas as palavras e proteções serão ineficazes para aliviá-la.

\section{Modelo dual do luto}

O modelo dual do luto, criado por Schut e Stroebe (1999), busca compreender como o indivíduo que perdeu um ente querido passa pelo processo do luto. Segundo o autor, o processo de adaptação e construção de significado ocorre a partir de dois tipos de estratégias: orientação para a perda e orientação para a restauração.

O enfrentamento orientado para a perda demonstra a busca pela pessoa perdida e está centrada nos aspectos relacionados à pessoa falecida: laços afetivos, negação, evitar a realidade da morte, rememorar, ver fotografias, falar sobre o ente querido e anseio por sua proximidade. Também pode-se incluir nesse enfrentamento a ruminação, ou seja, sobre como seria a vida se não houvesse ocorrido à morte (Schut, \& Stroebe, 1999).

O enfrentamento orientado para a restauração refere-se aos ajustamentos recorrentes à perda e que constituem fontes de estresse com as quais as pessoas em situação de luto precisam lidar. Tais ajustamentos referem-se a responder às mudanças de reorganização da vida após a morte do ente querido e, também, quando o enlutado precisa assumir as tarefas que eram realizadas pela pessoa que morreu, retomar as próprias tarefas do dia a dia, fazer coisas novas e se distrair (Schut, \& Stroebe, 1999).

No enfrentamento voltado para a restauração, a pessoa em luto assiste a um filme, sai com amigos, passeia, viaja, faz contato social de uma forma geral. O enlutado busca desenvolver uma nova identidade, podendo usar como exemplo o fato de: o filho que perdeu o pai, passa a ser órfão, a esposa que perdeu o marido, passa a ser viúva.

Segundo o autor, a oscilação é a alternância entre um e outro. Em um momento a pessoa está voltada para a perda e em outro ela está voltada a restauração. A oscilação é um processo necessário, pois quem fica apenas na orientação voltada para a perda ou apenas na orientação voltada para a restauração não está elaborando um luto saudável.

No Modelo Dual do luto, ao aceitar a realidade da perda, a pessoa aceita que o seu mundo foi transformado. $\mathrm{O}$ enlutado experimenta a dor da perda e, ao mesmo tempo, necessita enfrentar tal situação, buscando retomar as atividades do cotidiano. Tal modelo aborda as estratégias de enfrentamento, como indicadores de bem-estar e saúde. A Figura representa o modelo dual do luto. 


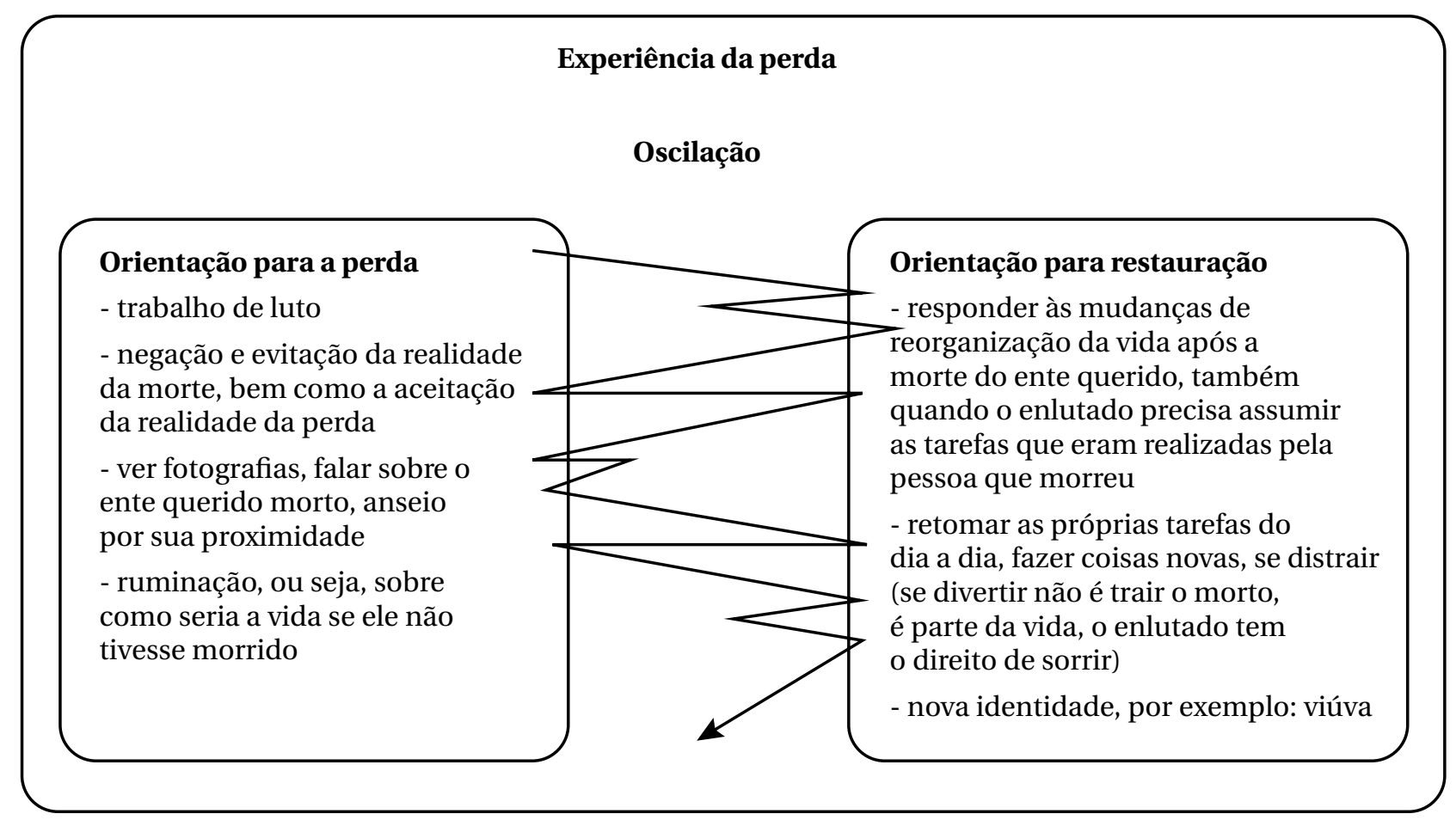

Figura 1

Modelo do processo dual do luto.

\section{Objetivos}

O objetivo geral do presente estudo foi investigar os aspectos emocionais no processo de luto de jovens adultos que perderam um dos pais pelo câncer, tais como: medo, tristeza, ansiedade, raiva e, algumas vezes, o alívio.

Como objetivo específico, buscou identificar as formas que os jovens adultos vivenciaram a terminalidade de um dos pais e compreender como passaram a enxergar a vida após vivenciar a morte de perto.

\section{Método}

\section{Participantes}

Participaram da pesquisa quatro jovens adultos, com a faixa etária entre 25 a 35 anos, de ambos os sexos, sendo dois homens e duas mulheres, que estavam passando pelo processo de luto num período máximo de dois anos, devido falecimento de um dos pais que foram acometidos pelo câncer. Uma das participantes foi indicada pelo Hospital Beneficência Portuguesa, enquanto os outros foram localizados por meio da rede de contato pessoal das pesquisadoras. Os dados sociodemográficos dos participantes estão sistematizados na Tabela. Ressalta-se que nela a identidade dos participantes foi preservada, utilizando os nomes fictícios.

\section{Procedimento de coleta de dados}

Inicialmente, o projeto foi apresentado ao setor de oncologia do Hospital Beneficência Portuguesa a fim de adquirir indicações da instituição para as pesquisadoras e, posteriormente, poderem entrar em contato com os familiares (jovens adultos) que perderam um de seus pais pelo câncer.

Foi feito de acordo com a Resolução $n^{\circ}$ 016/2000 do Conselho Federal de Psicologia (2000), que ressalva que toda pesquisa em Psicologia realizada com seres humanos tem a obrigação de ser apreciada pelo Comitê de Ética em pesquisa pela instituição acadêmica. Então, após a aprovação do Hospital Beneficência Portuguesa, o projeto foi encaminhado ao Comitê de Ética do Centro Universitário Barão de Mauá, pelo qual o foi analisado e aprovado (Anexo A).

Para o início da coleta de dados, os participantes foram contatados via telefone para agendamento da entrevista. Os dados foram coletados na casa de cada participante, com horário previamente agendado. 
Tabela

Perfil sociodemográfico dos enlutados.

\begin{tabular}{|c|c|c|c|c|c|}
\hline Participantes & Idade & Estado Civil & Grau de Escolaridade & Falecido(a) & Tempo da Perda \\
\hline João & 28 & Solteiro & Superior Completo & Pai & 2 anos \\
\hline Sueli & 35 & Solteira & $\begin{array}{l}\text { Ensino Médio } \\
\text { Completo }\end{array}$ & Mãe & 1 ano \\
\hline Fernando & 25 & Solteiro & Superior Completo & Mãe & 3 meses \\
\hline Maria & 35 & Casada & Superior Completo & Mãe & 2 anos \\
\hline
\end{tabular}

Nota.Fonte: Recuperado de Busa, \& Silva (2016, p. 28).

\section{Instrumentos}

Foram utilizadas entrevistas semiestruturadas, contendo questões que abordavam desde a terminalidade dos pais até o luto dos dias atuais. Junto com a entrevista, foi usado um gravador do início ao final de cada entrevista, com o objetivo de o trabalho ser o mais fiel possível aos relatos dos participantes, os quais foram depois transcritos e analisados na íntegra.

\section{Considerações éticas}

Baseados na Resolução nº 466/2012 do Ministério da Saúde - Diretrizes e Normas Regulamentadoras de Pesquisas Envolvendo Seres Humanos (Ministério da Saúde, 2012), os aspectos éticos foram considerados por meio do Termo de Consentimento Livre e Esclarecido (TCLE) que contempla todas as informações necessárias para os participantes, em linguagem clara e objetiva, buscando esclarecer sobre a pesquisa da qual participaram, além de garantir o sigilo das informações obtidas, a liberdade para desistência em qualquer fase da pesquisa e a assistência ao participante. O documento possui duas vias, uma para o participante e outro para as pesquisadoras.

É importante ressaltar também que toda pesquisa com seres humanos envolve certo risco, quer seja de aspecto físico, psíquico, moral, intelectual, cultural ou espiritual. Dessa maneira, buscou-se avaliar os possíveis riscos e minimizá-los. Os participantes estavam cientes de que as respostas foram gravadas e transcritas posteriormente. Caso alguma questão provocasse algum desconforto psicológico, o procedimento poderia ter sido interrompido temporariamente ou por definitivo.

\section{Tratamento dos dados}

O tratamento de dados foi realizado a partir dos pressupostos teóricos da análise de conteúdo de Bar- din (2010). Tal método envolve um conjunto de técnicas de análise das comunicações que utilizam procedimentos sistemáticos e objetivos de descrição do conteúdo das mensagens.

A análise de conteúdo constitui-se em três etapas analíticas, sendo elas a pré-análise, a exploração do material e o tratamento de dados. Os objetivos da pré-análise são pautados na escolha dos instrumentos a serem utilizados na análise e na formulação das hipóteses.

$\mathrm{Na}$ etapa da exploração do material estudam-se os documentos que foram escolhidos na pré-análise, com a finalidade de transformar e agregar os dados brutos em unidades, o que necessita de prática de leituras, codificação e enumeração, para poder descrever com exatidão as características relevantes do conteúdo e também propor as categorias e subcategorias como unidades através do relato.

Por fim, no tratamento de dados, as interpretações e discussões da coleta são realizadas com precisão, fazendo uso dos pressupostos teóricos citados neste estudo. Nessa etapa, procura-se entender o significado dos resultados obtidos e, partindo dessa compreensão, o pesquisador poderá propor além das interpretações, inferências a respeito dos objetivos previstos ou também de descobertas inesperadas (Bardin, 2010).

Minayo, Deslandes e Gomes (2002), ressalva a importância da pesquisa qualitativa partindo de uma realidade que não pode ser mensurada, trabalha com a imensidade dos significados, crenças e valores e que segue um espaço aprofundado das relações e dos fenômenos, podendo ser reduzidos à operacionalização de variáveis.

Vale ressaltar, que o caráter qualitativo da análise busca ter um olhar mais minucioso dos dados, com o objetivo de não só considerar o resultado final, mas também todo processo pelo qual ocorreu. 


\section{Resultados e discussão}

Visando compreender os objetivos propostos por este trabalho, articulam-se os resultados encontrados na coleta de dados com estudos sobre o tema. A partir dos relatos dos participantes, foi possível observar as semelhanças e particularidades entre as experiências e sentimentos vivenciados pelos jovens adultos que perderam um dos pais pelo câncer.

Nota-se que o diagnóstico do câncer representa para a família a possibilidade de morte, rompendo o equilíbrio individual. Tal fato foi constatado pelos relatos dos participantes que associaram o descobrimento da doença com o medo da morte.

Esses dados são congruentes com os estudos de Carvalho (2003), ao mencionar que o câncer suscita no homem vários tipos de medos da morte: a que provoca rupturas; como erro; como fracasso; como dor e como alívio. A incidência em maior ou menor grau dos tipos de medos citados depende das características individuais de cada membro do sistema, sua história, crenças e da dinâmica existente na família. As falas de Fernando e Sueli ilustram tal situação:

Não sei o que te dizer, assim, é uma doença complicada. Tem câncer mais fácil, se descobrir no início tem cura, mas tem doença... pra mim se der uma doença dessa, sei lá... se for grave, tem que ir trabalhando com a hipótese da morte já [...] Da morte até que não, né? Eu tenho medo da doença... assim, de sofrer como ela, como a minha mãe sofreu, eu passei esses momentos com ela, eu vi o quanto ela sofreu. Tenho medo do sofrimento, mas da morte assim, não (Fernando, 25 anos).

Eu não sei, que nem eu penso, o câncer eu acho que todo mundo nasce com ele, mas eu acho que chega uma época, algum mecanismo, algum negócio que não tá funcionando direito e ele acaba aparecendo. Eu acho que é isso, eu acho, creio eu (Sueli, 35 anos).

A literatura salienta que os sentimentos no momento da morte costumam ser muito variados em relação à intensidade e à frequência. É provável que surja um sentimento de tristeza profunda com o que está acontecendo e o medo do caminho desconhecido a ser percorrido, juntamente com o temor perante as inevitáveis mudanças (Jaramillo, 2006).

Percebe-se que todos os jovens adultos da pesquisa afirmaram vivenciar inúmeros sentimentos no processo do luto, surgindo assim uma ambivalência afetiva. Um dos participantes disse: "Porque a hora que você recebe a notícia é um bum, aí você não sabe se você está decepcionado por não ter feito nada, ou se é medo do que vai acontecer". A oscilação envolvida nos aspectos emocionais é evidenciada nas falas abaixo:

Eu tava desesperada, eu queria fazer algo que parasse a dor, que ela não gemesse, não chorasse mais de dor [...] Quando ela morreu, eu me senti confortável, porque ela não ia tá no hospital, não ia tá doendo, ninguém ia tá furando ela mais, que mais? Eu não ia ouvi ela andar de madrugada e ficá quieta gemendo de dor... Então eu senti tranquilidade (Sueli, 35 anos).

No comecinho, eu dormia chorando, acordava chorando, eu fiquei muito baqueado mesmo, sabe? Eu ficava pensando na probabilidade de ela morrer o tempo todo, sabe? Eu pensava muito, então eu chorava no comecinho, foi aquele baque [...] Mas no finalzinho, na última semana, assim, a gente até conversou e falou que se fosse continuar tanto sofrimento, era melhor pedir para Deus aliviar o sofrimento (Fernando, 23 anos).

Observa-se que conversar sobre a morte de um dos pais é uma questão delicada para os jovens adultos, surgindo divergência entre os participantes; dois deles preferem não conversar a respeito para não expor o processo da morte do seu ente querido, já Fernando relatou não se importar em discorrer sobre o tema.

Baseado nos estudos de Echeverri (2006), algumas pessoas sentem alívio com um abraço protetor, ao ter um ombro para chorar, ao compartilhar informações com alguém, sentindo urgência de falar, enquanto que, para outras, a situação é tão esmagadora que precisa retê-la, processá-la silenciosamente, não conseguindo colocar em palavras suas vivências, buscando retomar o controle.

Tais divergências são evidenciadas pelas falas dos participantes:

É tranquilo, eu tento não expor, aqui eu estou expondo porque sei que é um trabalho de vocês. Mas eu tento não expor todo o processo. Que foi pra lá, pra cá, o que aconteceu, o que não aconteceu, pra não ficar uma questão assim, ah, faleceu 
estava com câncer. Eu explico, faleceu de linfoma (João, 28 anos).

Eu sempre fui tranquilo. Tem gente que tem um bloqueio, não gosta de falar, mas eu sempre fui... se as pessoas perguntam, eu converso normal, respondo, explico [...] Quando me perguntam sobre o assunto, ah, não, eu não sinto nada. Porque as pessoas... é uma forma... sei lá, eu respondo tudo, é uma forma de saber... de saber como a gente está. Eu aceito tranquilo (Fernando, 23 anos).

Porque assim, tudo bem que a pessoa pergunta por educação, mas é uma dor que ninguém se acostuma, então não adianta perguntar pra mim se eu tô bem, dá vontade de falar assim: Idiota, eu não tô bem, porque olha a situação. E aí, como a cidade é pequena, e todo mundo conhecia ela, ficam perguntando: Ah, como que você tá? Tô péssima. [risos]. Tenho vontade de ficar quieta, não queria que ninguém me perguntasse nada (Maria, 35 anos).

Baseado nos relatos dos participantes, nota-se que o tempo cronológico em que ocorreu a morte dos pais tem influência sobre seus sentimentos e atitudes. Raimbault (1979) afirma que independente do tempo preciso para elaboração do luto, a superação está mais relacionada com a diminuição da presença do falecido, resultando em uma imagem internalizada que passa a fazer parte apenas da memória do enlutado.

Segundo os estudos de Worden (2013), apesar de existir uma consciência que sabe da perda real e a aceita, ainda se faz necessário um tempo maior para um acordo no campo afetivo. Tal fato se mostra nas falas das participantes:

Ainda está sendo difícil, tá? A gente era muito apegada, então ainda sinto falta de muita coisa, por exemplo, domingo ainda é bem difícil para mim, porque tem dois anos já, só que você fala, nossa, dois anos já daria pra se recuperar [...] Porque tudo o que acontece de bom ou de ruim, a primeira coisa que penso é assim: Nossa, tenho que falar pra minha mãe. E eu esqueço, sabe assim? Quando você esquece que ela faleceu? (Maria, 35 anos).

Dia 12 de junho vai fazer um ano que minha mãe faleceu [...] Bom, tá muito difícil, né? Nós duas éramos muito amigas e eu dependia muito dela, porque eu tive uma doença e ela que cuidava de mim, agora eu estou me recuperando sozinha, e tá fazendo muita falta [...] Em pensamento eu tô sempre conversando. Aí falam: o que você tá fazendo? Eu tô pensando aqui, eu tô conversando com ela mentalmente (Sueli, 35 anos).

Domingos e Maluf (2003) ressaltam que a perda que o jovem adulto sofre pode resultar em uma maior valorização da vida e em uma abertura para notar o que a mesma tem a oferecer de bom. Isso pode ser ilustrado na fala de três dos participantes:

Eu acho que dar valor nas pequenas coisas, a gente vive uma vida corrida e não olha as pequenas coisas, se apegar aos pequenos detalhes, tomar um café da manhã na mesa, jantar, almoçar, hoje eu me apego nesses pequenos detalhes, sabe? Eu faço questão disso, daquilo, questão de estar junto, estar perto, é um sentido que eu peguei para mim (João, 28 anos).

O que eu aprendi? Que a vida não tem que ser vivida amanhã, tem que ser vivida agora. Ai, amanhã, não! É hoje! Eu não sei o que vai acontecer daqui a 24 horas, é que nem o Guillain Barré, de manhã eu tava bem, à tarde já não. Entendeu? (Sueli, 35 anos).

Eu penso que você tem que viver a vida de uma maneira boa, enquanto você tem saúde e tudo mais, e... depois, se chegar a hora... mas acho que é aproveitar cada minuto, né? O dia a dia, viver... tem que aproveitar a vida (Fernando, 25 anos).

Jaramillo (2006), afirma que há momentos em que se pode enfrentar a morte com decisão, clareza e serenidade, enquanto, em outros, a reação será como a de crianças assustadas e se opta pelo consolo artificial de fechar os olhos, pretendendo ignorar aquilo que inspira terror.

Tal afirmação é congruente aos estudos de Schut e Stroebe (1999), criadores do modelo dual do luto. Os autores afirmam que, a pessoa que está em luto, oscila entre a perda e a restauração, ora lidando com os aspectos da morte, como chorar, olhar fotografias; e, em outros momentos, tentam seguir à diante com a vida, organizando a rotina $\mathrm{e}$ buscando outros caminhos. 
Pode-se verificar que alguns participantes discorreram sobre as formas que utilizaram para lidar com a perda:

Na verdade, eu vou sempre ao psicólogo, eu acho que é importante por vários fatores, eu não me sinto uma pessoa forte, então eu gosto de ir, tem dia eu que eu chego lá e não converso nada, tem dia que eu falo que eu vim só porque tem que vim [risos] [...] Mas eu gosto de conversar, eu não acho que eu nasci preparada pra ficar sem ela, então é muito difícil, eu não ficaria assim se eu não procurasse ajuda, eu acho que eu não estaria falando com vocês hoje, entendeu? (Maria, 35 anos).

Eu vejo que meu irmão se afundou muito no trabalho e eu também. Então, antes eu tentava não viajar muito, né? Quando meu pai estava junto com a minha mãe, por conta da minha namorada ser daqui também, ficava mais aqui, com isso, agora, eu optei mais por viajar, então, toda semana estou num lugar para não ficar mais naquele dia a dia, todo dia eu vou em casa e meu pai não está, então procuro outras saídas (João, 28 anos).

Observa-se que a religião foi um aspecto presente na fala de todos os participantes. O temor da morte é inato no ser humano e gera sentimentos difíceis de comunicar, não racionalizáveis. Pensar que a existência continuaria de outra forma, como alma, energia, natureza, ir para o céu, são construções imaginárias da civilização, são crenças que ajudam a lidar com a angústia existencial (Echeverri, 2006). É o que se pode perceber na fala de Sueli:

Sou reikiana e umbandista [...] É, aí na hora que ia dando o horário, eu falava: "Uai, a minha mãe não tá mais no hospital, que estranho”. Aí eu lembrava e ia pro quarto e rezava pra ela, e foi assim" (João, 28 anos).

João e Maria demonstraram uma confusão no sentido religioso:

Tipo assim, não que ele não exista, mas por que morre bebê de um ano? Então assim... se pra esse lado não tem como ajudar, não adianta querer que salva isso ou aquilo. Não sei se é ele que faz, né? A gente rezou muito, pediu que ajudasse, mas assim, não sei se ele ajuda (João, 28 anos).

Não, não vou mais em lugar nenhum, também não vou na católica, não vou em nenhuma, mas o meu conceito é de espírita, ela sempre falava assim ó: vocês sabem que eu tô passando por isso, porque eu tenho que passar. [...] Aí tudo bem, ela criou a gente com essa doutrina de espírita também, só que eu falo assim, mas que Deus que é esse? Que deixa os outros sofrerem, eu não consigo acreditar! Não é que eu não seja crente, eu sinto sim que existe uma força maior, por isso que a gente consegue ficar em pé, senão a gente não conseguiria (Maria, 35 anos).

Após a morte de um dos pais, todos os participantes da pesquisa relataram que se aproximaram da família e de amigos para serem amparados no momento de dor. Baseado na importância que os jovens adultos atribuíram à família e aos amigos durante o processo, percebe-se que ter a companhia de alguém empático e respeitoso nesse momento contribui para o enfrentamento da dor.

Certamente, na família ou no meio de amigos próximos há alguém com uma qualidade especial, que expressa empatia. Em alguns casos, uma ajuda profissional calorosa, comprometida e com a capacidade de receber o sofrimento sem julgá-lo, tornará o caminho menos solitário (Jaramillo, 2006). Para ilustrar essa questão, podemos recorrer a fala de Fernando e João:

Tipo assim, a gente procura estar unido, né? Tipo, continuar unido, vou muito nos meus irmãos, agora assim... de vez em quando, meu tio está na chácara e ele chama a gente para ir lá, para dar força para o meu pai né? Para ele não ficar muito sozinho (Fernando, 25 anos).

Porque não depende só de você. Entra uma série de pessoas que te seguram, seus avós, tios, amigos, parentes, que estruturam seu chão. Porque se você ficar sozinho, realmente você não aguenta. Quando acontece isso, mas está todo mundo do seu lado te amparando e dando os caminhos para isso ou aquilo (João, 28 anos).

Acho que o meu marido, acho que ele foi assim, é... Na última semana em que o médico falou que não tinha mais jeito, ele me levou lá todos os dias, 
e é uma hora de viagem, estrada, assim, horrível daqui pra lá (Maria, 35 anos).

Através dos relatos dos participantes, constata-se que além dos jovens-adultos, a família também está passando por um momento de mudança. Após a morte, a família sofre uma desorganização na sua forma de vida; assim, ao mesmo tempo em que presta apoio, também precisa de cuidado. As mudanças que acarretarão e as adaptações que essa família realizará dependem dos recursos disponíveis (Ortiz, 2005).

Pode-se observar essa situação, nos relatos dos participantes:

Unia a família, parentes, igual, a parte da família dele, não que a gente não tenha mais contato, mas agora é menos, distanciou bastante [...] Por conta do falecimento do meu pai, não que distanciou, ainda tem minha mãe que mora lá e tudo mais, mas assim, é um pouco complicado. Nós, a família, amadurecemos bastante (João, 28 anos).

Meu irmão é mais do que eu, era os três, sabe? Tudo agarradinho, um apegado ao outro. Ah, aí depois que ela se foi, você sabe, né? Sempre tem aquelas brigas, aquelas rusgas [...] meu pai se recuperou, tá namorando, tem vida nova e eu não simpatizo muito com a mulher não! Mas, ele tem a vida dele e eu a minha, né? Tanto é que eu falei pra ele: não interfira na minha, que eu não interfiro na sua. E estamos bem assim [...] O meu pai, o temperamento dele, porque ele sempre foi uma pessoa explosiva, sempre de cara fechada, de repente chega uma mulher na minha casa, ele se transforma (Sueli, 35 anos).

Aos cacos. O câncer, ele detona acho que tudo na família [...] Então ele acaba com tudo, a família fica assim... a gente continua até hoje se reunindo, porque era uma coisa que ela sempre pedia, mas no primeiro ano, a gente se encontrava e ninguém conseguia conversar. A gente ia e ficava assim: horas e horas sem falar nada (Maria, 35 anos).

Finalizando, pode-se dizer que os objetivos propostos com o presente estudo foram atingidos. Pode-se apreender, a partir dos depoimentos coletados, que os jovens-adultos que perdem um dos pais pelo câncer passam por oscilações dos aspectos emocionais, apresentando: ansiedade, tristeza, raiva, medo e algumas vezes, o alívio. Notou-se também que, após vivenciarem uma proximidade com a morte, passaram a valorizar a vida e o momento com os familiares e amigos.

Esses achados indicam que a atenção aos jovens adultos que perderam um dos pais pelo câncer é de suma importância durante o processo de luto, levantando, assim, possibilidades de elaboração de novas estratégias na rede de saúde, tais como: grupos de jovens adultos que passam pelo luto, orientação e apoio emocional.

\section{Considerações finais}

Os resultados da presente pesquisa são congruentes aos da literatura no que se refere aos sentimentos que os jovens adultos enfrentam após a morte de um dos pais pelo câncer. O luto é uma das situações mais dolorosas que existe, visto que é preciso percorrer algumas fases para ocorrer sua consumação, as quais abarcam sentimentos como tristeza, raiva e certo alívio. Nesse período, é importante realizar um trabalho de acolhimento.

A literatura aponta em demasia o quanto o câncer é estigmatizado como doença fatal, tanto socialmente como subjetivamente, desde o recebimento do diagnóstico. Nesse sentido, revela-se a necessidade de se pensar a respeito da finitude.

O luto surge como consequência dessa facticidade, levantando a uma das dores mais difíceis de vivenciar. Com base nos dados coletados, nota-se que o falecimento dos pais suscita uma variedade de sentimentos, como o medo do desconhecido, a tristeza e até certa tranquilidade devido ao fim do sofrimento do ente querido.

A rede de apoio psicossocial torna-se um suporte essencial, demonstrando que o jovem adulto pode se sentir deslocado ou perdido por não saber como agir perante tal situação, essa rede de apoio formada por pessoas próximas como família e amigos podem acolher e orientar.

A perda de um dos pais pode circunstanciar em mudanças radicais na vida do jovem adulto, tais como maiores responsabilidades e amadurecimento. Tal perda também pode despertar uma modificação do olhar para a vida, passando a valorizar situações que antes passavam despercebidas, assim como as pessoas próximas, a família e os amigos. 
O presente estudo buscou, através das informações levantadas, contribuir nas formas de trabalho do psicólogo, com o intuito de auxiliar no acolhimento e na escuta diferenciada, ajudando o jovem adulto enlutado a elaborar sua perda. No entanto, ainda há muito em que se adentrar a respeito do luto para essa faixa etária e as suas especificidades nas formas de enfrentamento.
Portanto, diante das limitações metodológicas deste estudo, como o tempo para a coleta de dados, essa pesquisa não possui o intuito de findar o conhecimento sobre o assunto, mas de contribuir para novas possibilidades de pesquisa e construção de conhecimento sobre o luto, valorizando ações de apoio e acolhimento para jovens adultos enlutados.

\section{Referências}

Ariés, P. (2014). O homem diante da morte. São Paulo, SP: Universidade Estadual Paulista.

Bardin, L. (2010). Análise de conteúdo. Lisboa: 70.

Bowlby, J. (2004). Apego e Perda: Tristeza e depressão. São Paulo, SP: Martins Fontes.

Busa, A.L.A., \& Braga, G.S., \& Rocha, F.P. (2016). O processo de luto na vida do jovem adulto decorrente da morte dos pais pelo câncer (Trabalho de conclusão de curso). Centro Universitário Barão de Mauá, Ribeirão Preto, SP, Brasil.

Carvalho, M. M. (2003). Introdução à psiconcologia. Campinas, SP: Psy.

Carvalho, V. (2010). Atendimento psicossocial a pacientes com câncer: Relato de uma experiência. In: M. Kóvacs, Morte e desenvolvimento humano (pp. 205-223). São Paulo, SP: Caso do Psicólogo.

Cunha, D., Freitas, L., \& Oliveira, M. (2011). Familiar cuidador de paciente com doença terminal frente ao processo do adoecimento. Psicologia.pt: Portal do Psicologo. Recuperado de http://www.psicologia.pt/artigos/textos/ TL0246.pdf

Domingos, B., \& Maluf, M. R. (2003). Experiências de perda e de luto em escolares de 13 a 18 anos. Psicologia: Reflexão e Crítica, 16(3), 577-589. https://doi.org/10.1590/S0102-79722003000300016

Echeverri, C. G. (2006). O grupo familiar diante da morte. In: I. F. Jaramillo, Morrer bem (pp. 68-86). São Paulo, SP: Planeta do Brasil.

Freud, S. (2010). Luto e melancolia. In: S. Freud, Introdução ao narcisismo, ensaios de metapsicologia e outros textos (1914-1916) (pp. 127-144). São Paulo, SP: Companhia das Letras.

Instituto Nacional de Câncer - INCA. (2016). O que é câncer? Brasília, DF: o autor. Recuperado de http://wwwl. inca.gov.br/conteudo_view.asp?id=322

Jaramillo, I. F. (2006). Morrer bem. São Paulo, SP: Planeta do Brasil.

Kovács, M. J. (2010). Morte e desenvolvimento humano. São Paulo, SP: Casa do Psicólogo.

Kübler-Ross, E. (2008). Sobre a morte e o morrer. São Paulo, SP: Martins Fontes.

Maranhão, J. (1992). O que é morte (3a ed.). São Paulo, SP: Brasilliense.

Minayo, M. C. S., Deslandes, S. F., \& Gomes, R. (Orgs.) (2002). Pesquisa social: Teoria, método e criatividade (20a ed.). Petrópolis, RJ: Vozes.

Ministério da Saúde. (2016). Diretrizes e normas regulamentadoras de pesquisas envolvendo seres humanos. Brasília, DC: o autor. Recuperado de http://conselho.saude.gov.br/resolucoes/2012/Reso466.pdf

Moraes, M. C. (1994). O paciente oncológico, o psicólogo e o hospital. In: M. M. M. J. Carvalho, Introdução à Psiconcologia (pp. 57-64). Campinas, SP: Psy.

Morin, E. (1997). O homem e a morte. Rio de Janeiro, RJ: Imago.

Ortiz, R. (2005). Cultura brasileira e identidade nacional (5a ed.). São Paulo, SP: Brasiliense.

Papalia, D., \& Olds (20013). Desenvolvimento humano (12a ed.). Porto Alegre, RS: Artmed McGraw Hill.

Parkes, C. (1998). Luto: Estudos sobre a perda na vida adulta. São Paulo, SP: Summus.

Raimbault, G. (1979). A criança e a morte: Crianças doentes falam da morte: Problemas da clínica do luto. Rio de Janeiro, RJ: Francisco Alves. 
Resolução CFP No 016/2000. Dispõe sobre a realização de pesquisa em Psicologia com seres humanos. Diário Oficial da União. 22 dez. 2000.

Schut, H., \& Stroebe, M. (1999). The dual process model of coping with bereavement: Rationale and description. Death Studies, 23(3), 197-224. https://doi.org/10.1080/074811899201046

Teixeira, L. (2006). Morte, luto e organização familiar: A escuta da criança na clínica psicanalítica. Psicologia Clínica, 18(2), 63-76. https://doi.org/10.1590/S0103-56652006000200006

Valle, E. R. M. (1997). Câncer infantil: Compreender e agir. Campinas, SP: Psy.

Worden, J. (2013). Aconselhamento do luto e terapia do luto: Um manual para profissionais de saúde mental (4a ed.). São Paulo, SP: Roca.

Zimerman, D. (2010). Fundamentos psicanalíticos: Teoria, técnica e clínica uma abordagem didática. Porto Alegre, RS: Artmed.

\section{Ana Laura Araujo Busa}

Psicóloga pelo Centro Universitário Barão de Mauá. Ribeirão Preto - SP. Brasil.

E-mail: analaura_busa@hotmail.com

(iD) http://orcid.org/0000-0002-5847-4407

Gabriela Braga da Silva

Psicóloga pelo Centro Universitário Barão de Mauá. Ribeirão Preto - SP. Brasil.

E-mail: gabi.b.s@hotmail.com

iD http://orcid.org/0000-0002-3716-4530

\section{Fernanda Pessolo Rocha}

Docente do curso de graduação em Psicologia do Centro Universitário Barão de Mauá. Ribeirão Preto - SP. Brasil. Coordenadora da Clínica Escola de Psicologia do Centro Universitário Barão de Mauá.

E-mail: fernanda.rocha@baraodemaua.br

http://orcid.org/0000-0001-9318-490X

Recebido 08/08/2017

Aceito 05/11/2018

Received 08/08/2017

Approved 11/05/2018

Recibido 08/08/2017

Aceptado 05/11/2018

Como citar: Busa, A.L.A., Braga, G.S., Rocha, F.P. (2019). O luto do jovem adulto decorrente da morte dos pais pelo câncer. Psicologia: Ciência e Profissão, 39, 1-16. https://doi.org/10.1590/1982-3703003183780

How to cite: Busa, A.L.A., Braga, G.S., Rocha, F.P. (2019). Young Adult Mourning Due to Cancer's Death of Parent. Psicologia: Ciência e Profissão, 39, 1-16. https://doi.org/10.1590/1982-3703003183780

Cómo citar: Busa, A.L.A., Braga, G.S., Rocha, F.P. (2019). El Luto del Joven Adulto Resultante de la Muerte de los Padres por el Cáncer. Psicologia: Ciência e Profissão, 39, 1-16. https://doi.org/10.1590/1982-3703003183780 